\title{
Effects of birth weight and standardized litter size on growth performance of boars and subsequent reproductive performance
}

\author{
A. Pietruszka\#, E. Jacyno, A. Sosnowska \& M. Kawęcka \\ Department of Pig Breeding, Animal Nutrition and Food, Faculty of Biotechnology and \\ Animal Husbandry, West Pomeranian University of Technology in Szczecin, Poland
}

(Received 7 November 2016; Accepted 12 May 2017; First published online 22 May 2017)

\begin{abstract}
Copyright resides with the authors in terms of the Creative Commons Attribution 4.0 South African Licence.
See: http://creativecommons.org/licenses/by/4.0/za

Condition of use: The user may copy, distribute, transmit and adapt the work, but must recognise the authors and the South African Journal of Animal Science.
\end{abstract}

\begin{abstract}
The aim of this study was to investigate the effects of birth weight and rearing litter size on growth and reproductive performance of boars. One hundred and forty male piglets were allotted to two groups, based on litter size: a smaller litter (SL) (8 piglets/litter, 70 boars) and a larger litter (LL) (12 piglets/litter, 70 boars). The boars in these litters were separated into two birth weight subgroups: lower birth weight (LBW) (mean: $1.15 \mathrm{~kg}, 70$ boars) and greater birth weight (GBW) (mean: $1.59 \mathrm{~kg}, 70$ boars). Testes volume, sexual activity and semen quality of boars at 180 days old were evaluated. The males in the GBW group, when compared with the LBW group, had greater bodyweight at 21, 28, and 63 days old $(P<0.01)$ and 180 days old $(P$ $<0.05)$, greater testes volume and semen volume $(P<0.05)$, greater sperm concentration and total number of sperm in the semen $(P<0.01)$ and a longer ejaculation time $(P<0.05)$. The boars in the SL group had greater $(P<0.01)$ bodyweight at 21 and 28 days old, greater $(P<0.05)$ sperm concentration and total number of sperm in the semen than boars in the LL group. These results indicate that birth weight is a good predictor of sperm production in adult boars and suggest the possibility of increasing sperm production in adult boars by reducing the litter size in which they are reared.
\end{abstract}

Keywords: Boars, bodyweight, piglets, reproduction, semen

\#Corresponding author: Arkadiusz.Pietruszka@zut.edu.pl

\section{Introduction}

The genetics of selection for pig prolificacy has led to an increase in litter size. However, there have also been increases in the proportion of low birth weight piglets and bodyweight variability in litters (Morise et al., 2008; Foxcroft, 2010). In addition, piglets reared in large litters have lower growth rates during lactation than those reared in small litters (Flowers, 2001). Rearing piglets in larger litters has also been shown to have negative effects on their reproductive performance as adult pigs (Ashworth, 2013).

Few studies have assessed the effects of birth weight and litter size of male piglets during lactation on shaping the reproductive potential of adult boars. However, Almeida et al. (2013) and Smit et al. (2013) observed that one-week-old male piglets with low birth weight had lower testes weight and number of Sertoli cells per testis than their heavier counterparts at birth. This suggests that low birth weight may reduce potential for sperm production in adult boars, because the number of Sertoli cells established before puberty determines sperm production as an adult (McCoard et al., 2003). The positive relationship between sperm production in adult boars and their birth weight was confirmed by Estienne \& Harper (2010) and Dysart (2014). Lin et al. (2015), observed the beneficial effects of birth weight on sperm production, testes volume and the numbers of Leydig and Sertoli cells in the distal portion of the testes in adult boars.

In studies that examined the relationship between litter size during lactation and subsequent reproductive performance in boars, it was found that boars reared in smaller litters have greater bodyweights and testes at weaning and greater sperm production at 180 days old than their counterparts that are reared in larger litters (Flowers, 2001; Flowers, 2011; Kawęcka et al., 2013).

Although few in number, previous studies suggest that the negative effects of low birth weight could be reduced by decreasing litter size during the suckling period. Therefore, the objective was to examine the effects of birth weight of male piglets and size of litter in which they were reared on reproductive (testes volume, sexual activity and semen quality) and growth performance during lactation and after weaning until puberty. 


\section{Materials and methods}

This study was conducted on boars of Polish Synthetic Line 990 in the Experimental Station of the National Institute of Animal Production, Krakow, Poland. Line 990 is the result of crossing pig breeds, namely Hampshire, Duroc, Polish Large White and various lines of Landrace. The experiment was conducted in accordance with the standards approved by the Animal Ethics Committee.

The evaluated boars were born from Polish Synthetic Line 990 sows of 2-4 parity and litters with 1113 piglets. On the first day after birth, litters of 80 sows were standardized to 8 (40 litters) or 12 (40 litters) piglets per sow. Before the standardization of litters, all piglets were individually weighed. Each litter contained equal numbers of males and females of similar birth weight.

In the present study, only 33 smaller and 32 larger litters in which there was no piglet mortality in suckling period were included. From each litter, 1 or 2 boars with birth weight above the average of the litter and 1 or 2 boars with a birth weight below the average were evaluated. A total of 140 boars were divided into two groups, depending on the litter size in which they were reared, namely SL and LL. Within litters boars were separated in two groups according to their birth weights, namely LBW and GBW. The experimental design is as shown in Table 1.

Table 1 Experimental research design

\begin{tabular}{|c|c|c|c|c|}
\hline & \multicolumn{2}{|c|}{ SL (8 piglets) } & \multicolumn{2}{|c|}{ LL (12 piglets) } \\
\hline & $\begin{array}{c}\text { LBW } \\
(0.95-1.29 \mathrm{~kg})\end{array}$ & $\begin{array}{c}\text { GBW } \\
(1.35-1.92 \mathrm{~kg})\end{array}$ & $\begin{array}{c}\text { LBW } \\
(0.95-1.30 \mathrm{~kg})\end{array}$ & $\begin{array}{c}\text { GBW } \\
(1.35-1.98 \mathrm{~kg})\end{array}$ \\
\hline No. of boars & 35 & 35 & 35 & 35 \\
\hline No. of litters & 33 & 33 & 32 & 32 \\
\hline
\end{tabular}

SL: smaller litter; LL: larger litter; LBW: lower birth weight; GBW: greater birth weight

The boars were weighed at 21 and 28 days old (at weaning). From 28 to 63 days old, all boars remained in farrowing pens, and were fed a standard diet of nutritive value according to recommendations of the Polish Standards of Pig Feeding (2014). At 63 days old, the boars were weighed and transferred to individual pens without straw, measuring $1 \times 2 \mathrm{~m}$, with a partly slatted floor (approximately $40 \%$ ), where they remained to the end of the performance test (180 days old). During this period, the males were fed a diet of $13 \mathrm{MJ}$ metabolizable energy, $187 \mathrm{~g}$ crude protein, $10.5 \mathrm{~g}$ lysine, $6.7 \mathrm{~g}$ methionine with cystine, $6.7 \mathrm{~g}$ threonine, and $2 \mathrm{~g}$ tryptophan per $1 \mathrm{~kg}$. Water was provided by nipple drinkers. Feed intake was measured daily.

At 180 days old, the boars were weighed and the testes volume was measured. The males were then trained to mount a dummy sow and semen collection began. During semen collection, the sexual activity of boars was evaluated, based on the number of mounts on the dummy sow before ejaculation began, the time from which the boar mounted the dummy sow and remained on the dummy sow until ejaculation began, and the duration of ejaculation.

The dimensions (length and width) of each testis were determined with Vernier callipers. The skinfold thickness (two layers of scrotal skin) were subtracted from initial measurements of length and width of each testis. Testis volume was calculated according to a formula described by Young et al. (1986):

$$
\mathrm{T}=4 / 3 \pi a b^{2}
$$

where: $\mathrm{T}=$ testis volume $\left(\mathrm{cm}^{3}\right)$

$$
\pi=3.14, \mathrm{a}=\text { length testis }(\mathrm{cm})
$$

$\mathrm{b}=$ width testis $(\mathrm{cm})$

Semen was collected using the gloved hand technique from a boar trained to mount a dummy sow. The evaluation of semen from each boar was performed on three ejaculates, collected at $7 \pm 1$ day intervals. During the collection, semen was filtered through gauze and only the sperm-rich fraction was collected. The mean values were obtained from the average of three ejaculates for each boar.

Shortly after collection these evaluations were performed: semen volume, sperm concentration in $1 \mathrm{ml}$ (haemocytometric method in Bürker's chamber), percentage of sperm progressive motility (subjectively by 
light microscopy Nikon, Eclipse E200, Tokyo, Japan, at $200 \times$ magnification) and total number of sperm in semen (sperm concentration $\times$ semen volume).

Sperm defects were classified as major or minor, by evaluating the frequency of the appearance of particular forms of morphologically changed sperm (Bloom, 1981). The percentage of sperm with normal apical ridge (NAR) acrosome (according to Pursel et al., 1972) was determined microscopically (at $400 \times$ magnification) in preparations stained with eosin and nigrosin. An osmotic resistance test (ORT) of acrosomal membranes was performed according to Schilling \& Vengust (1987).

The results are presented as arithmetic means $(\bar{x})$ and polled standard error of mean (polled SEM). The data were subjected to analysis of variance (ANOVA) using the MIXED procedure. The model for all evaluated traits included litter size, birth weight and litter size $x$ birth weight interaction as a fixed effects and order parity of sows in which the litters were standardized as random effect. The significance of difference $(P)$ between means was determined using Duncan's multiple range test. Statistical data analysis was carried out using Statistica computational software (Statistica PL, Krakow, Poland; version 12).

\section{Results}

By design, the average birth weight in the LBW group was lower $(38 \% ; P<0.01)$ than in the GBW group, whereas the average birth weight of boars reared in smaller (SL) and larger litters (LL) was similar (Table 2). The males in the GBW group when compared with the LBW group had greater $(P<0.01)$ average daily weight gain in the suckling period and greater bodyweight at age 21, 28, 63 days $(P<0.01)$ and 180 days $(P<0.05)$. In lactation, the average daily gain and bodyweight of the boars reared in smaller litters were greater $(P<0.01)$ than in larger litters (Table 2). However, at 63 and 180 days old, the bodyweights of boars in the $S L$ and $L L$ groups were similar.

Table 2 Effects of birth weight and litter size on growth performance of boars

\begin{tabular}{|c|c|c|c|c|c|c|c|c|}
\hline \multirow{2}{*}{ Specification } & \multicolumn{2}{|c|}{ BW groups } & \multicolumn{2}{|c|}{ LS groups } & \multirow{3}{*}{ SEM } & \multirow{3}{*}{$\begin{array}{c}P \\
\text { value } \\
\text { BW }\end{array}$} & \multirow{3}{*}{$\begin{array}{c}P \text { value } \\
\text { LS }\end{array}$} & \multirow{3}{*}{$\begin{array}{c}P \text { value } \\
\text { interaction } \\
B W \times L S\end{array}$} \\
\hline & LBW & GBW & SL & LL & & & & \\
\hline No. of boars & 70 & 70 & 70 & 70 & & & & \\
\hline Average birth weight $(\mathrm{kg})$ & 1.15 & 1.59 & 1.37 & 1.36 & 0.02 & $<0.01$ & NS & NS \\
\hline \multicolumn{9}{|l|}{ Average bodyweight $(\mathrm{kg})$ : } \\
\hline - at 21 days old & 5.24 & 6.52 & 6.06 & 5.70 & 0.11 & $<0.01$ & $<0.01$ & NS \\
\hline - at 28 days old & 6.96 & 8.73 & 8.12 & 7.62 & 0.13 & $<0.01$ & $<0.01$ & NS \\
\hline - at 63 days old & 19.67 & 22.38 & 21.40 & 20.64 & 0.25 & $<0.01$ & NS & NS \\
\hline - at 180 days old & 107.5 & 113.9 & 111.1 & 109.5 & 0.71 & $<0.05$ & NS & NS \\
\hline \multicolumn{9}{|l|}{ Average daily gain (g) } \\
\hline - from 1 to 28 days old & 216.4 & 266.5 & 250.3 & 232.5 & 4.03 & $<0.01$ & $<0.01$ & NS \\
\hline - from 63 to 180 days old & 751.7 & 780.0 & 769.8 & 761.8 & 4.68 & NS & NS & NS \\
\hline $\begin{array}{l}\text { Feed } / \text { gain from } 63 \text { to } 180 \text { days } \\
\text { old }(\mathrm{kg} / \mathrm{kg})\end{array}$ & 3.01 & 2.89 & 3.00 & 2.92 & 0.03 & NS & NS & NS \\
\hline
\end{tabular}

BW: birthweight; LS: litter size; LBW: lesser birth weight $(0.95<1.30 \mathrm{~kg})$; GBW: greater birth weight $(1.35<1.98 \mathrm{~kg})$ LS groups: SL: smaller litter (8 piglets/litter); LL: larger litter (12 piglets/litter)

$\mathrm{SEM}=$ polled standard error of means

NS $=$ not significant

At 180 days old, the volumes of left and right testis and of both testes of males in the GBW group were greater $(P<0.05)$ than in the LBW group, while the testes volume of males reared in SL and LL groups were similar (Table 3). 
Table 3 Effects of birth weight and litter size on testes volume and sexual activity of boars

\begin{tabular}{|c|c|c|c|c|c|c|c|c|}
\hline \multirow{2}{*}{ Specification } & \multicolumn{2}{|c|}{ BW groups } & \multicolumn{2}{|c|}{ LS groups } & \multirow{3}{*}{ SEM } & \multirow{3}{*}{$\begin{array}{c}P \\
\text { value } \\
\text { BW }\end{array}$} & \multirow{3}{*}{$\begin{array}{c}P \\
\text { value } \\
\text { LS }\end{array}$} & \multirow{3}{*}{$\begin{array}{c}P \text { value } \\
\text { interaction } \\
B W \times L S\end{array}$} \\
\hline & LBW & GBW & SL & LL & & & & \\
\hline No. of boars & 70 & 70 & 70 & 70 & & & & \\
\hline Volume of left testis $\left(\mathrm{cm}^{3}\right)$ & 280.3 & 297.9 & 292.3 & 285.7 & 8.21 & $<0.05$ & NS & NS \\
\hline Volume of right testis $\left(\mathrm{cm}^{3}\right)$ & 245.1 & 267.9 & 261.2 & 252.0 & 7.89 & $<0.05$ & NS & NS \\
\hline Volume of both testes $\left(\mathrm{cm}^{3}\right)$ & 524.5 & 566.0 & 553.7 & 537.5 & 15.68 & $<0.05$ & NS & NS \\
\hline $\begin{array}{l}\text { Time from mounting on a dummy } \\
\text { sow until the start of ejaculation } \\
\text { (s) }\end{array}$ & 91.53 & 82.07 & 87.89 & 85.71 & 3.69 & NS & NS & NS \\
\hline $\begin{array}{l}\text { Number of mounts before } \\
\text { ejaculation started }\end{array}$ & 1.40 & 1.25 & 1.30 & 1.38 & 0.04 & NS & NS & NS \\
\hline Duration of ejaculation (s) & 160.4 & 176.9 & 173.1 & 164.3 & 2.68 & $<0.05$ & NS & $<0.05$ \\
\hline
\end{tabular}

BW: birthweight; LS: litter size; LBW: lesser birth weight $(0.95<1.30 \mathrm{~kg})$; GBW: greater birth weight $(1.35<1.98 \mathrm{~kg})$ LS groups: SL: smaller litter (8 piglets/litter); LL: larger litter (12 piglets/litter)

$\mathrm{SEM}=$ polled standard error of means

NS $=$ not significant

The boars of greater birth weight had longer ejaculation time $(P<0.05)$ than the boars of lower birth weight. There was a significant interaction $(P<0.05)$ between birth weight $(\mathrm{BW})$ and litter size $(\mathrm{LS})$ for ejaculation time. The boars of greater birth weight in the SL group had a longer ejaculation time $(P<0.05)$ than the boars of greater birth weight in the LL group. In contrast, ejaculation duration was similar for lower birth weight pigs raised in larger or smaller litters (Table 4). The birth weight of males and litter size in which they were reared had no effect on other boar sexual activity parameters (Table 3 ).

Table 4 Interaction between birth weight and litter size for the duration of ejaculation

\begin{tabular}{lcccc}
\hline & \multicolumn{2}{c}{ LBW } & \multicolumn{2}{c}{ HBW } \\
\cline { 2 - 5 } & SL & LL & SL & LL \\
\hline No. of boars & 35 & 35 & 35 & 35 \\
Duration of ejaculation (s) & $161.1^{\mathrm{a}}$ & $160.1^{\mathrm{a}}$ & $185.1^{\mathrm{b}}$ & $168.2^{\mathrm{a}}$ \\
\hline a,b Means with different superscripts are significantly different at $P<0.05$ & & &
\end{tabular}

${ }^{a, b}$ Means with different superscripts are significantly different at $P<0.05$

The boars of greater birth weight had greater semen volume $(6.8 \% ; P<0.05)$, sperm concentration $(21 \% ; P<0.01)$ and total number of sperm in semen $(29.5 \% ; P<0.01)$ than the boars of lower birth weight (Table 5). The concentration of sperm and total number of sperm in the semen of boars reared in smaller litters were greater $(9.6 \%$ and $13 \%$, respectively; $P<0.05)$ than boars reared in larger litters. The birth weight of boars and litter size in which they were reared had no significant effect on the values of the other boar semen traits.

\section{Discussion}

The relationship between birth weight and weaning weight, as observed in the present study, is consistent with the findings of previous studies (Gondret et al., 2006; Beaulieu et al., 2010; Fix et al., 2010; Królewska et al., 2014), that reported that piglets with greater birth weights are heavier at weaning. According to Fix et al. (2010), greater bodyweight and faster weight gain of heavier piglets results from their greater number of muscle fibres and their dominance when competing for the most productive teats. Additionally, other authors have reported that the piglets of lower birth weight have fewer muscle fibres and less developed livers and small intestines, and as a result, they have a lower growth rate in the suckling period and post weaning compared with their counterparts with greater birth weight (Gondret et al., 2005; 
Rehfeldt \& Kuhn, 2006). In the current study, the boars of greater birth weight, compared with those of lower birth weight, have greater bodyweight at weaning and the later growth phase (to 180 days old). Similar results were observed in commercial market pigs (Beaulieu et al., 2010; Fix et al., 2010).

Table 5 Effects of birth weight and litter size on semen traits of boars

\begin{tabular}{|c|c|c|c|c|c|c|c|c|}
\hline \multirow{2}{*}{ Semen traits } & \multicolumn{2}{|c|}{ BW groups } & \multicolumn{2}{|c|}{ LS groups } & \multirow{3}{*}{ SEM } & \multirow{3}{*}{$\begin{array}{c}P \text { value } \\
\text { BW }\end{array}$} & \multirow{3}{*}{$\begin{array}{c}P \\
\text { value } \\
\text { LS }\end{array}$} & \multirow{3}{*}{$\begin{array}{c}P \text { value } \\
\text { interaction } \\
B W \times L S\end{array}$} \\
\hline & LBW & GBW & SL & LL & & & & \\
\hline No. of boars & 70 & 70 & 70 & 70 & & & & \\
\hline Semen volume (mL) & 107.9 & 115.2 & 113.2 & 109.6 & 1.00 & $<0.05$ & NS & NS \\
\hline Sperm concentration $\left(\mathrm{n} \times 10^{6} / \mathrm{mL}\right)$ & 175.2 & 212.6 & 202.6 & 184.9 & 6.51 & $<0.01$ & $<0.05$ & NS \\
\hline Total sperm in semen $\left(\mathrm{n} \times 10^{9}\right)$ & 18.90 & 24.47 & 22.93 & 20.27 & 0.73 & $<0.01$ & $<0.05$ & NS \\
\hline Sperm with progressive motility (\%) & 72.27 & 74.92 & 73.91 & 73.28 & 0.45 & NS & NS & NS \\
\hline Sperm with major defects (\%) & 13.90 & 12.61 & 12.93 & 13.58 & 0.52 & NS & NS & NS \\
\hline Sperm with minor defects (\%) & 13.41 & 13,97 & 13.90 & 13.49 & 0.54 & NS & NS & NS \\
\hline Sperm with normal acrosome (\%) & 86.85 & 87.59 & 87.45 & 87.00 & 0.78 & NS & NS & NS \\
\hline Osmotic resistance test (ORT) (\%) & 70.04 & 69.05 & 69.49 & 69.59 & 0.68 & NS & NS & NS \\
\hline
\end{tabular}

BW: birthweight; LS: litter size; LBW: lesser birth weight $(0.95<1.30 \mathrm{~kg})$; GBW: greater birth weight $(1.35<1.98 \mathrm{~kg})$ LS groups: SL: smaller litter (8 piglets/litter); LL: larger litter (12 piglets/litter)

$\mathrm{SEM}=$ polled standard error of means

$\mathrm{NS}=$ not significant

Piglets in smaller litters are not exposed to high competition, and can consume greater quantities of milk, which increases their weight gain. In the current study, boars reared in litters of eight piglets compared with their counterparts in litters of 12 piglets were significantly heavier only at weaning. Similar results were found for boars reared in litters of 7-10 and 11-16 piglets (Kawęcka et al., 2013). In contrast, boars reared in smaller litters (6 piglets/litter) had greater bodyweight up to 120 days old than those reared in litters of 12 piglets (Flowers, 2001).

The boars of average birth weight of $1.59 \mathrm{~kg}$ had significantly greater testes volume at 180 days old than boars weighing $1.15 \mathrm{~kg}$ at birth, while the litter size in which they were reared had no significant effect on testes volume at that time. Other studies have observed a similar relationship between testes size and birth weight in adult boars (Dysart, 2014; Almeida et al., 2015; Lin et al., 2015) or between testes size and litter size (Flowers, 2001; Kawęcka et al., 2013). Boar testes size may be an indicator of the number of Sertoli cells, as well as sperm production (Ford \& Wise, 2009; Ytournel et al., 2014; Jacyno et al., 2015). In the current study, there was a positive correlation between testes size and sperm production only in boars with different birth weights (GBW and LBW groups).

An important fact that was observed in the current study was the beneficial effects of greater birth weight or a reduction in the number of littermates on sperm production in boars. Sperm production is one of the most important factors that determine the reproductive performance of males. The main determinants of sperm production are Sertoli cells (Sharpe et al., 2003). The most active proliferation of Sertoli cell in pigs begins during the prenatal period and continues for about 30 days postnatal, which ultimately determines the potential for sperm production as an adult (França et al., 2000; McCoard et al., 2002; McCoard et al., 2003). Consequently, it is possible that a boar's potential for sperm production as an adult could be established by the time that it is weaned. Some studies have shown that the number of Sertoli cell in male testes during lactation (Almeida et al., 2013; Smit et al., 2013) and the total number of sperm per ejaculate in adult boars (Estienne \& Harper, 2010; Dysart, 2014; Lin et al., 2015) were positively correlated with birth weight in these individuals.

A significantly greater sperm concentration and total number of sperm in semen of boars reared in smaller litters versus larger litters, as observed in the current study, is consistent with previous reports (Flowers, 2001; Flowers, 2011; Kawęcka et al., 2013). This is probably as a result of an increase in the production of Sertoli cells during lactation in males of smaller litters. The boars in smaller litters can consume greater quantities of milk, which increases their weight gain and could intensify the proliferation of Sertoli cells in testicular tubules. Consequently, after reaching puberty, these boars may produce more sperm than 
boars reared in larger litters. In this study it was found that the impact of the birth weight on sperm production was on the level of $P<0.01$, whereas the litter size on the level of $P<0.05$.

There were no significant effects of birth weight and litter size on other semen traits (percentage of progressive motile sperm, sperm with major and minor defects, sperm with normal acrosome, osmotic resistance test). Similarly, Almeida et al. (2015) found that birth weight does not affect the semen quality of adult boars.

\section{Conclusion}

The results of this study confirm that birth weight is a good predictor of sperm production in adult boars and could be used as a selection criterion for replacement boars. The results also suggest the possibility of increasing sperm production in adult boars by reducing the litter size in which they were reared. Low birth weight in boars restricts their growth rate up to puberty (until 180 days old), while in larger litters it restricts growth rate only during lactation.

\section{Acknowledgements}

We are grateful to staff at the Experimental Station of the National Institute of Animal Production in Krakow for taking care of the animals and assistance of conducted experimental research.

\section{Authors' Contributions}

AP and EJ were responsible for experiment conception, supervision of project, execution of experiment, and paper edition. AS contributed to execution of experiment statistical analysis and the paper edition. MK contributed to execution of experiment, paper edition and final corrections.

\section{Conflict of Interest Declaration}

There is no conflict of interest that could compromise the impartiality of the research reported.

\section{References}

Almeida, F.R.C.L., Sacramento, R.C.R., Siqueira, A.P. \& Chiarini-Garcia, H., 2015. Birth weight effects on semen quality and reproductive performance of postpubertal boars. Reprod. Dom. Anim. 50 (suppl. 2), pp. 119.

Almeida, F.R.C.L., Auler, P.A., Moreira, G.H.F.A., Jardim, R.B.C., Bortolozzo, F.P. \& Chiarini-Garcia, H., 2013. Birth weight and its impacts on testicular development in boars. In: Control of pig reproduction IX. Edited by $\mathrm{H}$. Rodriguez-Martinez, H.M Soede \& W.L. Flowers., Context Products Ltd., Leics, UK. pp. 113-114.

Ashworth, Ch.J., 2013. Late pregnancy: The effects of intra-uterine life on production traits in offspring. Anim. Frontiers. 3 , 62-67.

Beaulieu, A.D., Aalhus, J.L., Williams, N.H. \& Patience, J.F., 2010. Impact of piglet birth weight, birth order, and litter size on subsequent growth performance, carcass quality, muscle composition, and eating quality of pork. J. Anim. Sci. 88, 2767-2778.

Blom, E., 1981. Studies on seminal vesiculitis in the bull: II. Proposal for a 249 new classification of the spermiogram. Med. Wet. 37, 239-242.

Dysart, N.E., 2014. Effect of birth weight and human socialization on the reproductive performance of adult A.I. boars. Department of Animal Sciences, North Carolina State University, Raleigh, USA, MSc thesis.

Estienne, M.J. \& Harper, A.F., 2010. Adult reproductive performance in high- and low-birth weight boars. J. Anim. Sci. 88 (E- suppl. 3), pp. 21.

Fix, J.S., Cassady, J.P., Herring, W.O., Holl, J.W., Culbertson, M.S. \& See, M.T., 2010. Effect of piglet birth weight on body weight, growth, backfat, and longissimus muscle area of commercial market swine. Livest. Sci. 127, 51-59.

Flowers, W.L., 2001. Influence of neonatal environment on sperm production of mature boars. NC State University. Department of Animal Sciences. Annual swine report.

Flowers, W.L., 2011. Managing gene by environment interactions on reproductive performance of replacement gilts and boars through pre-weaning management at multiplication level - Is this a reality? In: Proc. Allen D. Leman Swine Conference, St Paul, MN, USA. pp. 139-142.

Ford, J.J. \& Wise, T.H., 2009. Sertoli cell differentiation in pubertal boars. J. Anim. Sci. 87, 2536-2543.

Foxcroft, G.R., 2010. Gene x environment interactions affecting litter phenotype in commercial sows. J. Anim. Sci. 88 (Esuppl. 2), pp. 846.

França, L.R., Silva Jr., V.A., Chiarini-Garcia, H., Garcia, S.K. \& Debeljuk, L., 2000. Cell proliferation and hormonal changes during postnatal development of the testis in the pig. Biol. Reprod. 63, 1629-1636.

Gondret, F., Lefaucheur, L., Juin, H., Louveau, I. \& Lebret, B., 2006. Low birth weight is associated with enlarged muscle fiber area and impaired meat tenderness of the longissimus muscle in pigs. J. Anim. Sci. 84, 93-103.

Gondret, F., Lefaucheur, L., Louveau, I., Lebret, B., Pichodo, X. \& Le Clozler, Y. 2005. Influence of piglet birth weight on postnatal growth performance, tissue lipogenic capacity and muscle histological traits at market weight. Livest. Prod. Sci. 93, 137-146.

Jacyno, E., Kawęcka, M., Pietruszka, A. \& Sosnowska, A., 2015. Phenotypic correlations of testes size with semen traits and the productive traits of young boars. Reprod. Dom. Anim. 50, 926-930.

Kawęcka, M., Jacyno, E., Matysiak, B., Kołodziej-Skalska, A. \& Kamyczek, M., 2013. Performance of young boars depending on the litter size. Acta Sci. Pol. Zoot. 12, 15-24. 
Królewska, B., Rekiel, A. \& Więcek, J., 2014. Effect of birth body weight of piglets on their rearing up to the age of 10 weeks. Ann. Warsaw Univ. of Life Sci. - SGGW, Anim. Sci. 53, 21-28.

Lin, Y., Cheng, X., Sutovsky, P., Wu, Che, L.Q., Fang, Z.F., Xu, S.Y., Ren, B. \& Dong, H.J., 2015. Effect of intra-uterine growth restriction on long-term fertility in boars. Reprod. Fertil. Dev., http://dx.doi.org/10.1071/RD15130.

McCoard, S.A., Wise, T.H. \& Ford, J.J., 2002. Expression levels of müllerian-inhibiting substance, GATA-4 and 17ahydroxylase/17, 20-lyase cytochrome P450 during embryonic gonadal development in two diverse breeds of swine. J. Endocrinol. 175, 365-374.

McCoard, S.A., Wise, T.H., Lunstra, D.D. \& Ford, J.J., 2003. Stereological evaluation of Sertoli cell ontogeny during fetal and neonatal life in two diverse breeds of swine. J. Endocrinol. 178, 395-403.

Morise, A., Louveau, I. \& Le Huërou-Luron, I., 2008. Growth and development of adipose tissue and gut and related endocrine status during early growth in the pig: impact of low birth weight. Animal 2, 73-83.

Polish Standards of Pigs Feeding, 2014. Institute of Animal Psyhology and Nutrition, Polish Academy of Sciences, Warsaw, Poland. pp. 1-94.

Pursel, V.G., Johnson, L.A. \& Rampacek, G.B., 1972. Acrosome morphology of boar spermatozoa incubated before cold shock. J. Anim. Sci. 34, 55-64.

Rehfeldt, C. \& Kuhn, G., 2006. Consequences of birth weight for postnatal growth performance and carcass quality in pigs as related to myogenesis. J. Anim. Sci. 84 (E- suppl.), pp. 113-123.

Schilling, E. \& Vengust, M., 1987. Frequency of semen collection in boars and quality of ejaculates as evaluated by the osmotic resistance of acrosomal membrane. Anim. Reprod. Sci. 12, 283-290.

Sharpe, R.M., McKinnell, C., Kivlin, C. \& Fisher, J.S., 2003. Proliferation and functional maturation of Sertoli cells, and their relevance to disorders of testis function in adulthood. Reproduction 125, 769-784.

Smit, M.N., Spencer, J.D., Almeida, F.R.C.L., Patterson, J.L., Chiarini-Garcia, H., Dyck, M.K. \& Foxcroft, G.R., 2013. Consequences of a low litter birth weight phenotype for postnatal lean growth performance and neonatal testicular morphology in the pig. Animal 7, 1681-1689.

Young, L.D., Leymaster, K.A. \& Lunstra, D.D., 1986. Genetic variation in testicular development and its relationship to female reproductive traits in swine. J. Anim. Sci. 63, 17-26.

Ytournel, F., Brunet, E., Derks, P. \& Huisman, A.E., 2014. Testes size as predictor for semen production of boars and relation to female reproductive traits. In: Proc. 10th World Congress on Genetics Applied to Livestock Production, Vancouver, BC Canada. 